\title{
Additions to the Florula Marmarica
}

Author(s): Otto Stapf

Source: Bulletin of Miscellaneous Information (Royal Botanic Gardens, Kew), Vol. 1907, No. 9 ( 1907), pp. 365-369

Published by: Springer on behalf of Royal Botanic Gardens, Kew

Stable URL: http://www.jstor.org/stable/4111697

Accessed: 03-03-2016 20:52 UTC

Your use of the JSTOR archive indicates your acceptance of the Terms \& Conditions of Use, available at http://www.jstor.org/page/ info/about/policies/terms.jsp

JSTOR is a not-for-profit service that helps scholars, researchers, and students discover, use, and build upon a wide range of content in a trusted digital archive. We use information technology and tools to increase productivity and facilitate new forms of scholarship. For more information about JSTOR, please contact support@jstor.org. 
nullo. Flores disci numerosi ; tubus $1.2 \mathrm{~cm}$. longus, lobis ovatis Anthercue obtusae, $3 \mathrm{~mm}$. longae. Stylus glaber, stigmatibus glanduloso-pilosis. Achccenic plana, pilosa, $1 \mathrm{~cm}$. longa, 2-aristata, aristis $1.5 \mathrm{~mm}$. longis.

British EAst AfricA. Cultivated at Kew from seeds collected in British East Africa, by R. Diespecker.

This is a very handsome Coreopsis, and the most showy species yet introduced from Africa.

910. Haworthia Pearsoni, C. H. Wright [Liliaceae-Aloineae]; $H$. translucenti, Haw., affinis, foliis omnibus erecto-incurvatis primo aspectu differt.

Acaulescens. Folic circa 80, dense spiraliter congesta, oblanceolato-oblonga, in seta $7 \mathrm{~mm}$. longa, acuminata, $3 \mathrm{~cm}$. longa, $1.4 \mathrm{~cm}$. lata, $5 \mathrm{~mm}$. crassa, dilute viridia, dorso albo-striata, apice translucentia, supra convexa, subtus obtuse carinata et lineis duabus ciliarum instructa, mar'ginibus setaque albo-ciliatis. Scapus $25 \mathrm{~cm}$. longus, cylindricus, $2 \cdot 5 \mathrm{~mm}$. diam.; bracteae late deltoideae, cnspidatae, ped unculo appressae, albae, brunneo-carinatae; pedicelli $2 \mathrm{~mm}$. longi. Perianthium $1 \% \mathrm{~cm}$. Jongum, parte inferiore curvatum; segmenta oblonga, obtusa, dilute carnea, brunneocostati. Stceminc perianthio dimidio breviora.

SOUTH AFrica? Described from a plant received from Prof. H. H. W. Pearson, of Cape Town, in 1905, which flowered in the Succulent House at Kew in April, 1907.

This plant is allied to H.translucens, Haw. (Aloe arachnoides, var. tronslucens, Ker-Gawl. in Bot. Mag. t. 1417), which has fewer leaves with a different phyllotaxy, the outer ones spreading and the margins beset with flattened deltoid teeth, not with setae. In $H$. Pearsoni even the outermost leaves curve upwards.

\section{LVI.-ADDITIONS TO THE FLORULA MARMARICA.}

\section{O'ITO STAPF.}

Last year Mr. W. L. Balls, of Cairo, presented to Kew a set of plants collected in the neighbourhood of Mirsi Matruk, about $250 \mathrm{~km}$. west of Alexandria, by Dr. W. F. Hume, of the Geological Survey of Eyypt. Another set from the same district, but collected by Dr. John Ball, also of the Geological Survey of Egypt, was communisated quite recently by Prof. G. Schweinfurth in order that it might be included in the present article, the object of which is to register such species out of the two collections as are not yet recorded from the Marmarica, or at least the neighbourhood of Mirsa Matruk. Jr. Ball informs me that his plants came from an area situated between the coast (from a point about $5 \mathrm{~km}$. west of the fort of Mirsa Matruk to Ras Allem Rum) and a line about $15 \mathrm{~km}$. inland, and that they were collected in March, April, and May of 1903. The soil is mostly a calcareous loam. The term "Marmarica" is used here to cover the Egyptian littoral between Arab Bay and Bomba Bay, that is in the same sense as it is understood by Schweinfurth and Ascherson in their "Primitiae 
Florae Marmaricae" (Bull. Herb. Boissier, i., 1893). The enumeration following below is intended merely as "addenda" to their valuable paper, and for convenience the form and arrangement there adopted is adhered to, as well as their abbreviations, viz. :-

S. \& A.: Schweinfurth \& Ascherson, Primitiae Florae Marmaricae, in Bulletin de l'Herbier Boissier, vol. i., pp. 433-449, 584-603, 644-682, t. xx.

A. \& S.: Ascherson \& Schweinfurth, Illustration de la Flore de l'Egypt, in Mém. de l'Inst. Egypt, vol. ii., pp. 25-260.

\section{B.: Boissier, Flora Orientalis, vols. i.--v.}

$A$ at the end of the line indicates that the plant also occurs in Egypt; C, that it has been found in the Cyrenaica.

The species recorded for the first time from the Marmarica are marked with an asterisk $\left(^{*}\right)$.

Concerning the general conditions of the vegetation of the Marmarica, I would refer to the very interesting sketch of the phytogeography of the district in the first part of Schweinfurth and Ascherson's paper. Unfortunately there are no notes with either collection which would throw fresh light on the physiognomy or ecology of the vegetation. The additions are therefore of interest mainly in as far as they extend our knowledge of the constitution of the flora of the Marmarica.

*Roemeria dodecandra, Stapf, var. (?) laevis, Stapf (var. nov.) ; a forma typica differt omnibus partibus praeter foliorum imorum bases glaberrimis, foliorum laciniis anguste linearibus, carpellis stigmatisque lobis 4-5. (Coll. Hume.)

A very striking form. Unfortunately the material is too meagre to decide the question of its status as species or variety. Schweinfurth and Ascherson indicate a doubtful specimen of $R$. dodecandra from Matruk ; possibly it is the form described above.

Didesmus bipinnatus, DC.; S. \& A. 594. (Coll. Hume.)

This indicates a slight extension of the area of that species to the east, it not having been found, so far, beyond Tobruk.

Reboudia microcarpa, Coss.; S. \& A. 681 ; A. \& S. 40. Syn., Erucaria microcarpa, Boiss.; B., i., 366. (Coll. Ball.) C A

*Helianthemum vesicarium, Boiss. ; A. \& S. 45 ; B., i., 445 C
(Coll. Hume.)

Silene villosa, Forsk.; A.\& S. 46 ; B., i., 592. (Coll. Hume.) A Also in Algeria.

Throdium gruinum, Willd.; S. \& A. 599 ; A. \& S. 54 ; B., i., 892. (Coll. Bume.)

Ononis sicula, Guss.; S. \& A. 601 ; A.\& S. 61 ; B., ii., 60. (Coll. Ball.)

Trigonella stellata, Forsk.; S. \& A. 602 ; A. \& S. 61 ; B., ii., 85. (Coll. Ball.) 
*Trifolium resupinatum, L.; A. \& S. 63 ; B., ii., 137 . (Coll. Bume.)

Probably an escape from cultivation. Also in Algeria.

Hippocrepis multisiliquosa, $L . ;$ S. \& A. 603 ; A. \& S. 65 ; B., ii., 185. (Coll. Hume.)

*Astragalus Forskalii, Boiss. ; A. \& S. 67 ; B., ii., 392. (Coll. Hume.)

Not known, so far, west of Alexandria.

Ebenus Armitagei, Schweinf. \& Taub.; S. \& A. 645. (Coll. Ball.)

So far only known from a single locality in the small bay of Mirsa Badia, almost $200 \mathrm{~km}$. to the west of Mirsa Matruk.

The occurrence of this Ebenus in the Marmarica is phytogeographically very interesting. The genus is entirely absent in Egypt and Syria, and the nearest congener is found in Crete. This, $E$. cretica, L., is at the same time more closely allied to $E$. Armitagei than any other species. One other species occurs in North Africa, viz., E. pinnatus, Desf., ranging from Morocco to Tunis ; but this represents another type (section Onobrychioides, Jaub. \& Spach).

Vicia sativa, $L$., var. angustifolia, Alef.; S. \& A. 646 ; A. \& S. 68. Syn., V. angustifolia, All. ; B., ii., 574. (Coll. Hume.) C A

*V. calcarata, Desf. ; S. \& A. 646 ; A. \& S. 68 ; B., ii., 590. (Coll. Hume.)

A very narrow-leafed form, possibly identical with Boissier's variety cinerea (V. cinerea, M.B.), which is known from South Palestine and Tunis as the nearest localities.

Lathyrus Aphaca, L.; S. \& A. 647 ; A. \& S. 68 ; B., ii., 602. (Coll. Hume.)

L. Cicera, L. ; S. \& A. 647 ; A. \& S. 69 ; B., ii., 605. (Coll. Hume.)

*Aizoon hispanicum, $L$. ; A. \& S. 78 ; B., ii., 765. (Coll. Ball.) A The nearest locality to the west for this species is Sfax in Tunis.

Odontospermum pygmaeum, O. Hoffm.; A. \& S., Suppl., 7€0, 798; S. \& A. 652. Syn., Asteriscus pygmaeus, Cass. et Dur.; A. \& S. 85 ; B., iii., 179. (Coll. Ball.)

Also from Tunis to Morocco.

Gnaphalium luteo-album, L.; A. \& S. 88 ; B., iii., 224. (Coll. Bume.)

Subcosmopolitan.

Anthemis Ballii, Stapf (sp. nov.); affinis A. microspermae, Boiss. et Kotschy, sed foliis minus et arctius dentatis, receptaculo elongato, conico, acheniis distinctius costatis costis glandulosis diversa. (Coll. Ball.)

Herba annua, pumila, gracilis, $7 \mathrm{~cm}$. alta, e basi pauci-ramosa, caulibus tenuibus purpurascentibus inferne parce superne densius 
crispo-villosis. Folia linearia vel lineari-lanceolata, acuta, superiora integra, inferiora utrinque 2-3-dentato-lobata lobis approximatis ovatis mucronulatis, $5-7 \mathrm{~mm}$. longa, $1.5-3 \mathrm{~mm}$. lata, crassiuscula, villosula. Pedunculi graciles, apice nutantes neque incrassati, $1-1.5 \mathrm{~cm}$. longi. Involucrum tenuiter lanoso-villosulam phyllis exterioribus ovato-lanceolatis acutis, interioribus gradatim longi. oribus obtusioribus, intimis ad $4 \mathrm{~mm}$. longis obtusissimis late hyalino-marginatis. Receptaculum elongatum, conicum, 2-3 $\mathrm{mm}$. longum, paleis oblanceolatis acutis subcarinatis hyalino-scariosis. Ligulae albae, elliptico-oblongae, circiter $8 \mathrm{~mm}$. longae, femineae. Achaenia pallida obovoidea, apice rotundata, minute umbonata, calva, 8-costata, ad costas glandulosa.

This also resembles meagre specimens of $A$. deserti, Boiss., from which it differs in the conical receptacle and much smaller achenes.

"Calendula aegyptiaca, Desf.; A. \& S. 92 ; B., iii., 419. (Coll. Hume.)

Atractylis flava, Desf.; A. \& S. 93 ; S. \& A. 655 ; B., iii., 452. (Coll. Ball.)

-Amberboa Lippii, DC.; A. \& S. 95 ; B., iii., 606. (Coll. Bume.)

Westward from Tunis to the Canaries.

A. orupinoides, DC. ; S. \& A. 656 ; A. \& S. 95 ; B., iii., 606 . (Coll. Hume, Ball.)

Contaurea dimorpha, Viv. ; A. \& S. 96 ; S. \& A. 656 ; B., iii., 692. (Coll. Ball.)

C A

Picris coronopifolia, DC. ; A. \& S. 99 ; S. \& A. 657 ; B., iii., 740. (Coll. Ball.)

Urospermum picroides, Desf. ; S. \& A. 657 ; A. \& S. 99 ; B., iii., 743. (Coll. Hume.)

-Coris monspeliensis, L. ; A. \& S. 103. (Coll. Ball.)

This is generally a West Mediterranean plant and not taken up in Boissier's Flora Orientalis. Ascherson and Schweinfurth, l.c., quote it as very rare near Alexandria, this being the only record of the plant having been observed in Egypt; but there is also a specimen of it at Kew from Aucher Eloy's collection, numbered 2598, and written up as having been collected in Syria.

"Convolvulus arvensis, L.; A. \& S. 107 ; B., iv., 108. (Coll. Hume.)

Subcosmopolitan.

Cistanche lutea, Hoffm. \& Link. Syn., Phelipaea lutea, S. \& A. 661 ; A. \& S. 118 ; B., iv., 500. (Coll. Ball.)

Also throughout North-West Africa.

Salvia lanigera, Poir.; S. \& A. 662 ; A. \& S. 121. Syn., S. controversa, Ten. ; B., iv., 630. (Coll. Hume, Ball.)

Ramex vesicarius, L. ; S. \& A. 667 ; A. \& S. 134 ; B., iv., 1017. (Boll. Hume, Ball.) 
Tuphorbia Paralias, L.; S. \& A. 668 ; A. \& S. 138 ; B., iv., 1130 (Coll. Hume.)

Arisarum vulgare, Targ. Tozz. ; S. \& A. 669 ; A. \& S. 146 ; B., v., 44. (Coll. Hume.)

C A

"Ornithogalum tenuifolium, Guss., var. trichophyllum, Boiss. et Heldr. ; A. \& S. 151 ; B., v., 219. (Coll. Hume.)

Found only once by Ehrenberg near Alexandria.

"Allium roseum, L., var. Tourneuxii, Boiss. ; A. \& S. 152 ; B., v., 274. (Coll. Hume.)

Schweinfurth and Ascherson (Fl. Marm. 672) indicate under Allium Erdelii, Zucc., a barren specimen from Matruk collected by Roth and enumerated as $A$. roseum, v. Tourneuxii, in their Illustration de la Flore d'Egypte, p. 152. Dr. Hume's specimen is in flower, and there can be no doubt about its identity with the original of Boissier's variety Tourneuxii.

Trisetum Loeflingianum, Beauv.; S. \& A. 674. (Coll. Hume, Ball.)

Ascherson and Schweinfurth do not mention it in their Illustration de la Flore d'Egypte, but there are specimens at Kew collected by Figari near Alexandria and in the Thebais.

Koeleria phleoides, Per's. ; S. \& A. 675 ; A. \& S. 172 ; B., v., 572. (Coll. Huine.)

- Bromus scoparius, L., var. stenantha, Stapf (var. nov.) ; a forma typica differt spiculis ipsis et partibus earum omnibus angustioribus. (Coll. Hume.)

The typical form is known from the Cyrenaica and Northern Egypt, but has so far not been recorded from the Marmarica. The valves of the variety described here measure $10-1.1 \mathrm{~mm}$. by $2 \cdot 25-2 \cdot 75 \mathrm{~mm}$. (flattened out) and the tip above the insertion of the awn is frequently over 3 to $4 \mathrm{~mm}$. long, whilst the awn varies from 10-15 mm. in length. We have, what appears to me, the same state from Cyprus (Sintenis and Rigo, 367) and Syria (Post, 16(), 692, 695, 698).

Hordeum murinum, L. ; S. \& A. 677 ; A. \& S. 179 ; B., v., 686. (Coll. Hume.)

\section{LVII.-MISCELLANEOUS NOTES.}

Sansevieria grandis.-A specimen of fibre has recently been submitted to Kew for determination and for a report as to its commercial value. It was accompanied by a few leaves, which were sufficient to identify it as Sansevieria grandis, Hook. f. The sənder, Mr. H. L. Hall, General Merchant, etc., of "Riverside," Nelspruit, Transvaal, describes the plant as growing plentifully there, and remarks that the fibre sent was made up by the natives some time ago, but "as it is now winter and the dry season" (date of letter Aug. 3rd, 1907), the fibre in the leaf "is not as good as when gathered in the summer." Thus the uncertainty 